\title{
Jurnal
}

p-ISSN 2621-797X ; e-ISSN 2746-6841 DOI:10.32493

Jurnal Disrupsi Bisnis, Vol. 4, No. 4, Juli 2021 (275-284)

http://openjournal.unpam.ac.id/index.php/DRB/index

\section{Strategi Branding Merek Casual Culture. Co Di Surabaya Dalam Meningkatkan Penjualan}

\author{
Trio Noorsy Wahyudi ${ }^{1 *}$, Lia Nirawati ${ }^{2}$ \\ ${ }^{1,2}$ Fakultas Ilmu Sosial dan Ilmu Politik, Universitas Pembangunan Nasional "Veteran” Jawa Timur \\ ${ }^{1}$ Trionoorsywa@gmail.com*; ${ }^{2}$ lianirawatibisnisupn@gmail.com
}

Received 20 Mei 2021| Revised 10 Juni 2021 | Accepted 25 Juli 2021

*Korespondensi Penulis

\begin{abstract}
Abstrak
Penelitian ini, berfokus untuk mengetahui strategi branding yang dilakukan oleh CASUAL CULTURE.CO dalam meningkatkan penjualannya agar tetap menjadi pilihan konsumen dan tetap menjadi merek yang bisa berkembang di pasar bebas. Casual Culture.co adalah salah satu brand clothing yang ada di Surabaya yang menargetkan pangsa pasar tren semua kalangan khususnya anak muda. Tujuan penelitian ini juga dapat menggambarkan bagaimana mengimplementasikan atau cara branding yang dilakukan dan memperbaiki kelemahan yang dihadapi. Metode penelitian yang digunakan untuk penelitian ini adalah metode deskriptif yang merupakan bagian dari analisis kualitatif dengan menggunakan teknik pengambilan data secara observasi, dokumentasi dan wawancara mendalam yang berkaitan dengan strategi branding produk berdasarkan dengan menggunakan atribut produk yang meliputi, segi kualitas, fitur, desain, kemasan,label, pelayanan, jaminan, harga serta komponen identitas merek yaitu nama merek, logo dan simbol, slogan, karakter, jingle, URL/ Website yang digunakan oleh peneliti dalam menemukan kekuatan, kelemahan, peluang, dan ancaman dengan metode SWOT. Hasil dari penelitian ini dengan melalui analisis IFAS (Internal Strategy Factor Analisis Sumarry) dan EFAS (Eksternal Strategy Factor Analisis Sumarry) dapat diketahui bahwa Casual Culture memiliki skor dari faktor internal yaitu, kekuatan sebesar 1,83 dan kelemahan memiliki skor 1,12, sedangkan dari faktor eksternal memiliki skor peluang 1,61 dan skor ancaman 1,22. Pilihan strategi adalah SO, sehingga pada diagram SWOT terletak di kuadran I, yaitu perusahaan memiliki peluang dan kekuatan sehingga dapat memanfaatkan peluang yang ada sehingga strategu yang harus dilakukan adalah mendukung kebijakan pertumbuhan agresif (Growth Oriented Strategy).
\end{abstract}

Kata Kunci: Strategi Branding; Analisis SWOT

\begin{abstract}
This research, it focuses on knowing the branding strategy carried out by CASUAL CULTURE.CO in increasing its sales so that it remains a consumer choice and remains a brand that can develop in the free market. Casual Culture.co is a clothing brand in Surabaya that targets the trend market share of all circles, especially young people. The purpose of this study can also describe how to implement or how to do branding and improve the weaknesses faced. The research method used for this research is descriptive method which is part of a qualitative analysis using observational data collection techniques, documentation and in-depth interviews related to product branding strategies based on using product attributes which include, in terms of quality, features, design, packaging. , labels, services, guarantees, prices and components of brand identity, namely brand names, logos and symbols, slogans, characters, jingles, URLs / websites used by researchers in finding strengths, weaknesses, opportunities, and threats using the SWOT method. The results of this study. Through the analysis of IFAS (Internal Strategy Factor Analysis Sumarry) and EFAS (External Strategy Factor Analysis Sumarry) it can be seen that Casual Culture has a score of internal factors, namely, strengths of 1.83 and weaknesses have a score of 1.12, meanwhile from external factors it has an opportunity score of 1.61 and a threat score of 1.22. The choice of strategy is SO, so that the SWOT diagram is located in
\end{abstract}


quadrant I, where the company has opportunities and strengths so that it can take advantage of existing opportunities so that the strategy that must be done is to support aggressive growth policies (Growth Oriented Strategy).

Keyword: Branding Strategy; SWOT Analysis

\section{PENDAHULUAN}

Pada saat ini pakaian merupakan kebutuhan dasar bagi setiap orang untuk kehidupan sehari-hari Selain merupakan suatu kebutuhan yang penting, pakaian merupakan salah satu ekspresi tentang cara hidup, pakaian juga dapat mencerminkan perbedaan status antar kelompok masyarakat tertentu. Menurut Morris (2001), pakaian yang dikenakan oleh manusia memiliki tiga fungsi mendasar, yaitu memberikan kenyamanan, sopan-santun, dan pamer (display). Dengan demikian, cara kita memilih pakaian dapat berfungsi sebagai suatu pernyataan dan sebagai sarana untuk menunjukan penanda sosial (social signals) tentang si pemakainya.

Model pada busana dapat diartikan sebagai perubahan dalam gaya hidup seseorang yang berlangsung terus menerus. Model atau fashion adalah gaya hidup yang menjadi modus atau panutan pada masa tertentu dan tempat tertentu. Model selalu berubah-ubah sesuai dengan keadaan masyarakat dan bersifat dinamis serta berulang-ulang dalam jangka waktu tertentu. Perubahan tersebut disebabkan adanya pengaruh politik, sosial, ekonomi, dan psikologis masyarakat.

Menurut Jean Baudrillard (2011:74) adanya pengelompokan masyarakat berdasarkan selera bersama menjadi ide dari kapitalisme yang ditandai dengan adanya produksi masal sehingga muncul yang dinamakan consumer culture atau masyarakat konsumsi.

Fashion juga menjadi salah satu objek konsumsi penting dalam masyarakat modern. Dilihat dari tingkatan sosialnya, gaya berpakaian pada setiap lapisan masyarakat memiliki gaya yang berbeda beda. Begitu banyak pilihan model pakaian yang tersedia saat ini menyebabkan manusia dapat berpakaian sesuai dengan gaya hidup mereka.

Adanya Clothing Company yang mulai masuk di Indonesia tahun 1996 ditandai dengan berdirinya 347 boadrider.co yang sekarang lebih dikenal 347/eat. Seiring respon positif pasar dan berkembangnya zaman, kebutuhan dalam menunjang gaya hidup pun ikut berkembang. Perusahaan clothing akhirnya tidak hanya berfokus pada memproduksi kaos saja, namun juga ikut mengembangkan ide-ide menarik usahanya dalam memproduksi barang lainnya. Dengan hadirnya Clothing Line yang semakin banyak maka perkembangan Clothing Line ini dibarengi dengan hadirnya Distro (Distribution Store). Menurut Heru Rottensoul 2013, Distro berasal dari kata Distribution Store yang bisa diartikan sebagai tempat, outlet atau toko yang secara khusus mendistribusikan produk dari suatu komunitas, Biasanya berasal dari komunitas music band independent atau istilahnya band indie dan komunitas supporter sepak bola.

Budaya independent tersebut muncul dan berkembang sebagai tren fashion bernama streetwear, dunia fashion yang dinamis melahirkan kultur atau budaya memiliki banyak penggemar yaitu streetwear, jenis pakaian cenderung casual dan non formal. Kehadiran brand atau merek streetwear terkenal di dunia banyak di antaranya yang didasarkan oleh kecintaan atau kegemaran dalam budaya indepent yang tumbuh.

The American Marketing Association Rebranding (AMA) merumuskan Brand adalah sebagai nama, istilah, tanda, lambang, atau desain, atau kombinasi yang dimaksudkan untuk mengidentifikasi barang dan jasa dari satu penjual atau kelompok penjual dan mendiferensiasikan merek dari para pesaing" (Keller,2013)

Branding menurut Philip Kotler (2015) adalah pemberian nama, istilah, tanda, simbol, rancangan, atau kombinasi dari semuanya, yang dibuat dengan tujuan untuk mengidentifikasi barang atau jasa atau 
kelompok penjual dan untuk membedakan dari barang atau jasa pesaing. Beberapa komponen identitas merek menurut Keller (2013) yakni: nama merek, logo dan simbol, tagline/slogan, karakter/maskot, jingle Dan URL. Strategi Branding adalah Suatu manajemen brand yang bertujuan untuk mengatur semua elemen brand dalam kaitannya dengan sikap dan perilaku konsumen.

Di kota-kota besar di Indonesia tidaklah sukar menemukan merek global yang berlokasi berdekatan dan bersaing head-to-head dengan merek lokal. Oleh karenanya, kelangsungan hidup merek lokal di era kompetisi global merupakan isu menarik yang patut dikaji secara komprehensif. Kondisi ini sering terjadi di kota-kota besar khususnya di Surabaya karena tingginya permintaan yang ada dan banyaknya pesaing dengan produk serupa, seperti brand yang bernama Casual Culture.co. dengan mengusung konsep casual dan streetwear yang di usungnya sejak awal berdiri pada tahun 2014 ini merintis membangun pasarnya di komunitas-komunitas yang telah di bangunnya, dengan berkontribusi langsung kepada kultur atau budaya jalanan seperti music independent, komunitas skateboard, komunitas supporter dan graffiti yang cenderung memulainya dari jalanan.

Casual Culture.co adalah salah satu brand clothing yang ada di Surabaya yang menargetkan pangsa pasar tren semua kalangan khususnya anak muda. Berdirinya Casual Culture.co didirikan oleh sejumlah anak muda yang memiliki kegemaran dan ide yang sama tentang fashion jalanan yang biasa disebut casual streetwear. Dengan itu Casual Culture.co menghadirkan varian produk seperti kaos, sweater, hoodie, totebag, tas ransel, sling bag, polo shirt, kemeja, celana pendek, topi, beanie, dompet, payung dan sikat gigi.

Titik awal tren fashion lokal clothing mulai digemari anak muda, saat itu juga semakin tingginya minat konsumen tentang clothing brand lokal maka banyak juga pesaing pesaing dengan produk clothing brand lokal maupun luar negeri itu juga menjadikan Casual Culture.co sebagai motivasi untuk menciptakan produk dan ide-ide untuk dipasarkan sesuai target pasar yang ditujukan yaitu komunitas music, komunitas skateboard, komunitas supporter dan masyarakat umum lainnya.

Dengan adanya peningkatan dan penurunan penghasilan yang dialami oleh Casual Culture.co membuat peneliti ingin mempelajari lebih lanjut bagaimana cara pemasaran dan strategi branding yang dilakukan oleh Casual Culture.co dalam berjuang untuk mendapatkan tempat di pasar clothing brand di pasaran. Analisis SWOT salah satu cara yang dapat membantu para pelaku bisnis untuk mengalisa bagaimana strategi penjualannya dapat berjalan dengan lancer.

Menurut Rangkuti $(2016 ; 19)$ analisis SWOT adalah identifikasi berbagai faktor secara sistematis untuk merumuskan strategi perusahaan. Analisis ini didasarkan pada logika yang dapat memaksimalkan kekuatan (Strengths) dan peluang (Opportunities), namun secara bersamaan dapat meminimalkan kelemahan (Weaknesses) dan ancaman (Threats).

Analisis SWOT juga membantu para pelaku bisnis agar dalam mengoperasikan bisnisnya dapat berjalan sesuai rencana bisnis dan tercapai tujuannya. Pelaku bisnis harus mengakui apa saja kekuatan (strengths), kelemahan(weaknesses), peluang (opportunities), serta ancaman (threats) yang terdapat dalam kegiatan bisnisnya agar dapat melakukan strategi yang tepat sasaran dalam menjalankan bisnisnya.

Penelitian ini bertujuan untuk mengetahui dan menganalisis strategi branding yang dilakukan Casual Culture.co dalam meningkatkan penjualan.

\section{METODE}

Penelitian ini dilakukan pada Casual Culture.Co yaitu salah satu brand clothing yang ada di Surabaya yang menargetkan pangsa pasar tren semua kalangan khususnya anak muda. Metode penelitian yang digunakan yaitu metode deskriptif kualitatif dengan mempertimbangkan lebih cocok dan mudah apabila berhadapan dengan narasumber, dan juga lebih peka menghadirkan jawaban yang kompleks untuk menyimpulkan hasil penelitian yang dilakukan. 
Dalam penelitian deskriptif kualitatif penelitian dapat mendeskripsikan subjek penelitian sebagai informan, yang artinya orang pada latar penelitian yang dimanfaatkan untuk memberikan informasi tentang situasi dan kondisi latar penelitian. Sejalan dengan definisi tersebut, peneliti akan melakukan wawancara mendalam kepada pemilik dan juga karyawan Casual Culture.co, lalu wawancara terarah kepada sejumlah konsumen (purposive sample). Serta dilengkapi dengan observasi atas berbagai artifak desain pendukung branding.

Dalam teknik analisis data penelitian ini digunakan metode deskriptif dan kemudian digunakan analisis SWOT. Data deskriptif dihasilkan melalui wawancara mendalam (in-depht interview) kepada pemilik dan karyawan dengan strategi branding dengan menggunakan atribut produk yang meliputi segi Kualitas Produk, Fitur Produk, Desain, Kemasan, Label, Pelayanan, Jaminan dan Garansi, Harga, Merek Casual Culture.co, hasil wawancara tersebut akan dianalisis menggunakan metode analisis SWOT yang meliputi Strenght (Kekuatan), Weakness (Kelemahan), Opportunities (Peluang), dan Threats (Ancaman).

\section{HASIL DAN PEMBAHASAN}

\section{Strategi Branding}

1. Kualitas Produk

Produk yang ditawarkan oleh Casual Culture.co sangat bervariasi dan bermacam-macam mulai dari kebutuhan primer (pakaian) kaos, jaket, hoodie, celana pendek, polo shirt, kemeja, sweater, topi, beanie, dan juga ada accesoris seperti jam tangan, jam dinding, gelas, sikat gigi, korek api, slingbag, tas ransel, bantal, tempat minum, sisir dan yang terbaru ini adalah mousepad. Untuk pemilihan bahan baku yang digunakan Casual Culture.co sangat teliti mulai dari kain yang digunakan, cat sablon, dan bahan-bahan aksesoris lainnya selalu awasi dengan ketat, dan dilakukan quality control berulang kali.

2. Fiture Produk

Casual Culture mempunyai fitur yang menunjang produk yang di tawarkan di dalam toko yaitu: katalog, webstore, instagram, line official account, WhatsApp, kaca, ruang ganti, AC, rak baju, serta memiliki layanan pengiriman via online meliputi; go-send, Tokopedia, JNT, Shoppee.

3. Design

Design dari Casual Culture lebih mengarah ke Casual Streetweaar, seperti Supporter Sepak bola, Musik Independent, Graffiti, dan skateboard. Memilih tema tersebut karena juga kebutuhan pasar Casual Culture sendiri, konsep store juga di buat sesimpel mungkin dan senyaman mungkin untuk konsumen berbelanja.

4. Kemasan

Kemasan yang digunakan pada produk Casual Culture masih menggunakan plastik ziplock, tetapi Casual Culture sendiri membuat movment untuk mengurangi kantong plastik sekali pakai di setiap transaksi jual beli. Untuk itu Casual Culture melakukan perubahan dari penggunaan kantong plastik sekali pakai dengan shoppingbag, dengan bahan spunbund atau konsumen dapat membawa tas belanja sendiri.

5. Label

Casual Culture menggunakan label dengan desaign yang simpel sehingga dapat dilihat dengan jelas oleh konsumen, dan juga berisi tentang beberapa informasi yaitu cara merawat produk, logo, website, instagram, serta ukuran.

6. Pelayanan

Untuk pelayanan di toko dan sosial media Casual Culture semua karywan memiliki kewajiban yang sama pada saat melayani konsumen dengan ramah dan sopan, melakukan penawaran kepada konsumen memberikan informasi yang jelas kepada konsumen, dan memberikan edukasi kepada 
konsumen. Karena Casual Culture memegang erat prinsip yang di junjungnya yaitu "atittute above all" sampai dibuatkan produk kaos berdesain tersebut. Karyawan yang menjaga toko harus tetap menjaga kenyamanan dan kebersihan toko.

7. Jaminan

Casual Culture memberikan produk yang terbaik untuk dijual sehingga dapat diterima dan digunakan konsumen dengan hasil yang memuaskan, dengan itu Casual Culture memberikan jaminan jika konsumen menerima produk yang dibeli ada kerusakan atau minus, produk dapat di kembalikan atau ditukarkan dengan produk yang baru.

8. Harga

Harga yang di berikan Casual Culture dirasa sangat bersaing dengan harga clothing lain, harga yang ditentukan berdasarkan HPP produk dan menentukan laba, untuk mengetahui harga pokok penjualan dalam suatu produk. Untuk harga yang ditawarkan mulai dari Rp.125.000 sampai dengan Rp.300.000 tergantung dengan produk yang ditawarkan, berbeda dengan aksesoris yang ditawarkan seperti korek, keycan, gelas, dan lain lain mulai dari Rp.25.000 sampai Rp.150.000. dengan itu harga dapat menjadi daya tarik konsumen yang mencari kualitas yang bagus.

9. Merek

Arti dari sebuah nama Casual Culture.co sendiri yaitu budaya casual yang berarti membudayakan tetap berpakaian rapi dan pemilik menyukai salah satu bagian dari budaya di sepak bola, yang identik dengan mengoleksi brand brand ternama seperti Adidas, Nike, Losandele, Fred Perry, Stone Island, dan lain lain. Sebab itu pemilik mencetus penamaan tersebut. Untuk logo Casual Culture.co mengandung filosofi yaitu huruf $\mathrm{C}$ yang lebih besar untuk menunjukkan kalimat Culture yang paling di utamakan Brand ini. Proses branding yang dilakukan oleh Casual Culture.co berkaitan dengan produk yang ditawarkan agar menarik minat beli konsumen adalah aktif di sosial media terutama instragram yang memberikan informasi penting seperti jam buka toko, memberikan informasi barang yang masih tersedia atau tidak, peluncuran artikel baru dan aktif untuk upload produk yang tersedia di market place seperti shoppe dan tokopedia.

\section{Analisis SWOT Pada Casual Culture/.Co}

1. Strenght (kekuatan)

a. Memiliki kualitas produk yang bagus

b. Mampu mengeluarkan produk setiap bulannya

c. Memiliki tempat produksi sendiri dari beberapa produk

d. Sudah memiliki nama yang cukup besar di Surabaya

e. Memiliki design yang bagus dan menarik

f. Memberikan harga yang terjangkau dibandingkan dengan pesaing

g. Sering memberikan promo menarik

h. Promosi yang dilakukan di media sosial sangat menarik

2. Weakness (kelemahan)

a. Kurang mengatur manajemen organisasi internal yang terstruktur di bidangnya

b. Kurang kuatnya melakukan pemasaran di luar kota surabaya

c. Tidak memiliki slogan yang mempermudah untuk mendeskripsikan Merek Casual Culture.co

3. Opportunity (peluang)

a. Mengadakan kolaborasi dengan brand lain agar peluang pasar Casual Culture semakin luas.

b. Memaksimalkan perkembangan teknologi dengan adanya media sosial dan internet

c. Mengikuti pameran clothing pada event tertentu guna untuk menaikkan produk yang ditawarkan Casual Culture agar lebih dikenal masyarakat luas 
d. Mengedukasi konsumen mengenai support produk lokal, membuat image Casual Culture menjadi digemari kembali dan dapat bersaing dengan produk luar negeri yang serupa (Clothing).

e. Mengadakan kolaborasi dengan seniman lokal (Band, Graffiti) untuk deaign produknya.

f. Memiliki web resmi untuk memudahkan konsumen berbelanja online

g. Menambah design pakaian yang simple dan iconic agar diminati semua kalangan

4. Threat (ancaman)

a. Kurang tanggapnya dalam mencari informasi terkait trent yang sedang booming

b. Semakin banyaknya pesaing sejenis di bidang yang sama

c. Masih adanya masyarakat yang lebih memilih merek luar negeri yang lebih terkenal dibanding produk lokal sendiri.

d. Peraingan harga dengan brand baru yang harganya lebih rendah

Tabel 1. IFAS

\begin{tabular}{|c|c|c|c|c|c|}
\hline No & $\begin{array}{l}\text { Faktor - Faktor Strategi } \\
\text { Internal }\end{array}$ & Bobot & Rating & $\begin{array}{c}\text { Bobot X } \\
\text { Rating }\end{array}$ & Komentar \\
\hline $\mathbf{A}$ & Kekuatan & & & & \\
\hline 1 & $\begin{array}{l}\text { Memiliki kualitas produk } \\
\text { yang bagus }\end{array}$ & 0,15 & 4 & 0,45 & Dipertahankan \\
\hline 2 & $\begin{array}{l}\text { Mampu mengeluarkan produk } \\
\text { setiap bulannya }\end{array}$ & 0,07 & 3 & 0,21 & $\begin{array}{c}\text { Dipertahankan } \\
\text { dan ditingkatkan }\end{array}$ \\
\hline 3 & $\begin{array}{l}\text { Memiliki tempat produksi } \\
\text { sendiri dari beberapa produk }\end{array}$ & 0,08 & 3 & 0,24 & Dipertahakan \\
\hline 4 & $\begin{array}{l}\text { Sudah memiliki nama yang } \\
\text { cukup besar di Surabaya }\end{array}$ & 0,05 & 1 & 0,05 & $\begin{array}{l}\text { Dipertahankan } \\
\text { dan itingkatkan }\end{array}$ \\
\hline 5 & $\begin{array}{l}\text { Memiliki design yang bagus } \\
\text { dan menarik }\end{array}$ & 0,10 & 3 & 0,30 & Dipertahankan \\
\hline 6 & $\begin{array}{l}\text { Memberikan harga yang } \\
\text { terjangkau dibandingkan } \\
\text { dengan pesaing }\end{array}$ & 0,05 & 1 & 0,05 & Dipertahankan \\
\hline 7 & $\begin{array}{l}\text { Sering memberikan promo } \\
\text { menarik }\end{array}$ & 0,07 & 2 & 0,14 & Dipertahankan \\
\hline 8 & $\begin{array}{l}\text { Promosi yang dilakukan di } \\
\text { media sosial sangat menarik }\end{array}$ & 0,08 & 3 & 0,24 & $\begin{array}{c}\text { Dipertahankan } \\
\text { dan ditingkatkan }\end{array}$ \\
\hline & Total & $\mathbf{0 , 6 5}$ & & $\mathbf{1 , 8 3}$ & \\
\hline B & Kelemahan & & & & \\
\hline 1 & $\begin{array}{l}\text { Kurang mengatur manajemen } \\
\text { organisasi internal yang } \\
\text { terstruktur di bidangnya }\end{array}$ & 0,15 & 4 & 0,60 & $\begin{array}{l}\text { Diperbaiki dan } \\
\text { Ditingkatkan }\end{array}$ \\
\hline 2 & $\begin{array}{l}\text { Kurang kuatnya melakukan } \\
\text { pemasaran di luar kota } \\
\text { surabaya }\end{array}$ & 0,12 & 3 & 0,36 & Ditingkatkan \\
\hline 3 & $\begin{array}{l}\text { Tidak memiliki slogan yang } \\
\text { mempermudah untuk } \\
\text { mendeskripsikan Merek Casual } \\
\text { Culture.co }\end{array}$ & 0,08 & 2 & 0,16 & Diperbaiki \\
\hline & $\begin{array}{c}\text { Total } \\
\end{array}$ & $\mathbf{0 , 3 5}$ & & 1,12 & \\
\hline & Total Skor Internal & 1 & & 2,95 & \\
\hline
\end{tabular}

Dari hasil analisis tabel IFAS diatas, faktor kekuatan mempunyai nilai skor total $($ bobot $\mathrm{x}$ rating $)=1,83$ dan faktor kelemahan mempunyai nilai skor total $($ bobot $\mathrm{x}$ rating $)=1,12$ 
Tabel 2. EFAS

\begin{tabular}{|c|c|c|c|c|c|}
\hline No & $\begin{array}{c}\text { Faktor - Faktor Strategi } \\
\text { Pemasaran }\end{array}$ & Bobot & Rating & $\begin{array}{l}\text { BobotX } \\
\text { Rating }\end{array}$ & Komentar \\
\hline $\mathbf{A}$ & Peluang & & & & \\
\hline 1 & $\begin{array}{l}\text { Mengadakan kolaborasi dengan } \\
\text { brand lain agar peluang pasar } \\
\text { Casual Culture semakin luas. }\end{array}$ & 0,15 & 4 & 0,60 & $\begin{array}{l}\text { Dipertahankan } \\
\text { dan } \\
\text { Ditingkatkan } \\
\end{array}$ \\
\hline 2 & $\begin{array}{l}\text { Memaksimalkan perkembangan } \\
\text { teknologi dengan adanya media } \\
\text { sosial dan internet }\end{array}$ & 0,11 & 3 & 0,33 & $\begin{array}{l}\text { Dipertahankan } \\
\text { dan } \\
\text { Ditingkatkan } \\
\end{array}$ \\
\hline 3 & $\begin{array}{l}\text { Mengikuti pameran clothing pada } \\
\text { event tertentu guna untuk } \\
\text { menaikkan produk yang } \\
\text { ditawarkan Casual Culture agar } \\
\text { lebih dikenal masyarakat luas }\end{array}$ & 0,06 & 2 & 0,12 & Dipertahankan \\
\hline 4 & $\begin{array}{l}\text { Mengedukasi konsumen } \\
\text { mengenai support produk lokal, } \\
\text { membuat image Casual Culture } \\
\text { menjadi digemari kembali dan } \\
\text { dapat bersaing dengan produk } \\
\text { luar negeri yang serupa } \\
\text { (Clothing). }\end{array}$ & 0,05 & 1 & 0,05 & Ditingkatkan \\
\hline 5 & $\begin{array}{l}\text { Mengadakan kolaborasi dengan } \\
\text { seniman lokal (Band, Graffiti) } \\
\text { untuk deaign produknya. }\end{array}$ & 0,10 & 2 & 0,20 & Dipertahankan \\
\hline 6 & $\begin{array}{l}\text { Memiliki web resmi untuk } \\
\text { memudahkan konsumen } \\
\text { berbelanja online }\end{array}$ & 0,05 & 1 & 0,05 & $\begin{array}{l}\text { Dipertahankan } \\
\text { dan } \\
\text { Ditingkatkan } \\
\end{array}$ \\
\hline 7 & $\begin{array}{l}\text { Menambah design pakaian yang } \\
\text { simple dan iconic agar diminati } \\
\text { semua kalangan }\end{array}$ & 0,08 & 3 & 0,24 & $\begin{array}{l}\text { Dipertahankan } \\
\text { dan } \\
\text { Ditingkatkan }\end{array}$ \\
\hline & Total & $\mathbf{0 , 6 0}$ & & 1,61 & \\
\hline B & Ancaman & & & & \\
\hline 1 & $\begin{array}{l}\text { Kurang tanggapnya dalam } \\
\text { mencari informasi terkait trent } \\
\text { yang sedang booming }\end{array}$ & 0,06 & 2 & 0,12 & $\begin{array}{l}\text { Meningkatkan } \\
\text { Branding }\end{array}$ \\
\hline 2 & $\begin{array}{l}\text { Semakin banyaknya pesaing } \\
\text { sejenis di bidang yang sama }\end{array}$ & 0,15 & 3 & 0,45 & $\begin{array}{l}\text { Perlunya } \\
\text { membangun } \\
\text { kepercayaan } \\
\text { pada konsumen }\end{array}$ \\
\hline 3 & $\begin{array}{l}\text { Masih adanya masyarakat yang } \\
\text { lebih memilih merek luar negeri } \\
\text { yang lebih terkenal dibanding } \\
\text { produk lokal sendiri. }\end{array}$ & 0,07 & 2 & 0,14 & $\begin{array}{l}\text { Perlunya } \\
\text { Meningkatkan } \\
\text { Brandng }\end{array}$ \\
\hline \multirow[t]{3}{*}{4} & $\begin{array}{l}\text { Peraingan harga dengan brand } \\
\text { baru yang harganya lebih rendah }\end{array}$ & 0,12 & 3 & 0,36 & $\begin{array}{c}\text { Membangun } \\
\text { kepercayaan } \\
\text { konsumen } \\
\end{array}$ \\
\hline & Total & $\mathbf{0 , 4 0}$ & & 1,22 & \\
\hline & Total Skor Eksternal & l & & 2.83 & \\
\hline
\end{tabular}

Dari hasil analisis tabel EFAS diatas, faktor peluang mempunyai nilai skor total (bobot $\mathrm{x}$ rating) $=1,61$ dan faktor ancaman memiliki nilai skor total (bobot $\mathrm{x}$ rating) $=1,22$ 


\section{Diagram Analisis SWOT}

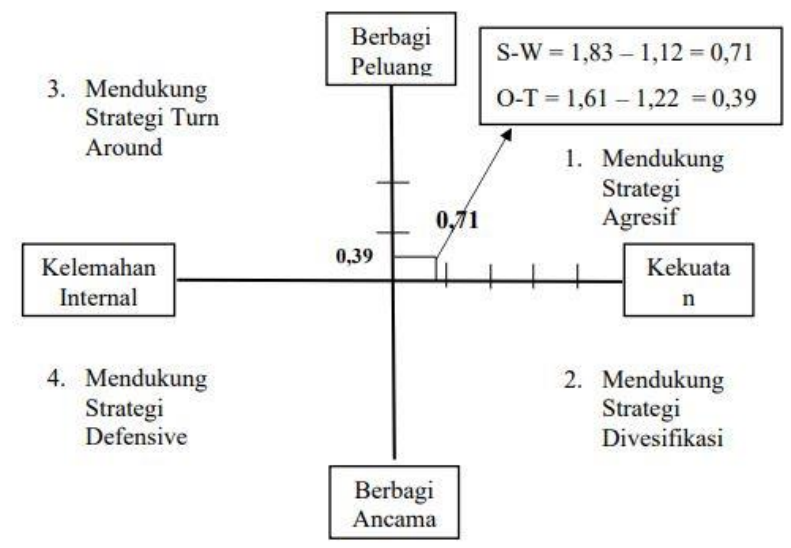

Gambar 1. Diagram Analisis SWOT

Dari hasil analisis diagram SWOT di atas menunjukkan bahwa usaha Casual Culture berada di kuadran 1 (satu). Kondisi ini merupakan situasi yang sangat menguntungkan. Pada kondisi tersebut Casual Culture dalam kondisi yang baik, sehingga sangat dimungkinkan untuk melakukan ekspansi, membesarkan pertumbuhan organisai dan meraih peluang secara maksimal demi kemajuan yang berkelanjutan perusahaan. Strategi yang harus digunakan terhadap kondisi seperti ini yaitu mendukung strategi agresif (growth oriented strategy).

\section{Rumusan Strategi Matrik SWOT}

Tabel 3. Rumusan Strategi Matrik SWOT

\begin{tabular}{|c|c|c|}
\hline IFAS & $\begin{array}{c}\text { Strengths } \\
\text { (Kekuatan) S }\end{array}$ & $\begin{array}{c}\text { Weakness } \\
\text { (Kelemahan) W }\end{array}$ \\
\hline Opportunity & Strategi SO & Strategi WO \\
\hline (Peluang) $\mathrm{O}$ & $1,83+1,61=3,44$ & $1,12+1,61=2.73$ \\
\hline Threats & Strategi ST & Strategi WT \\
\hline (Ancaman) $T$ & $1,83+1,22=3,05$ & $1,12+1,22=2,34$ \\
\hline
\end{tabular}

Setelah menghitung skor total dari faktor internal dan eksternal maka disusun matrik SWOT untuk menganalisis rumusan alternatif strategi SO, WO, ST, WT yang hasil analisisnya sebagai berikut

Tabel 4. Rumusan Alternatif Strategi SWOT

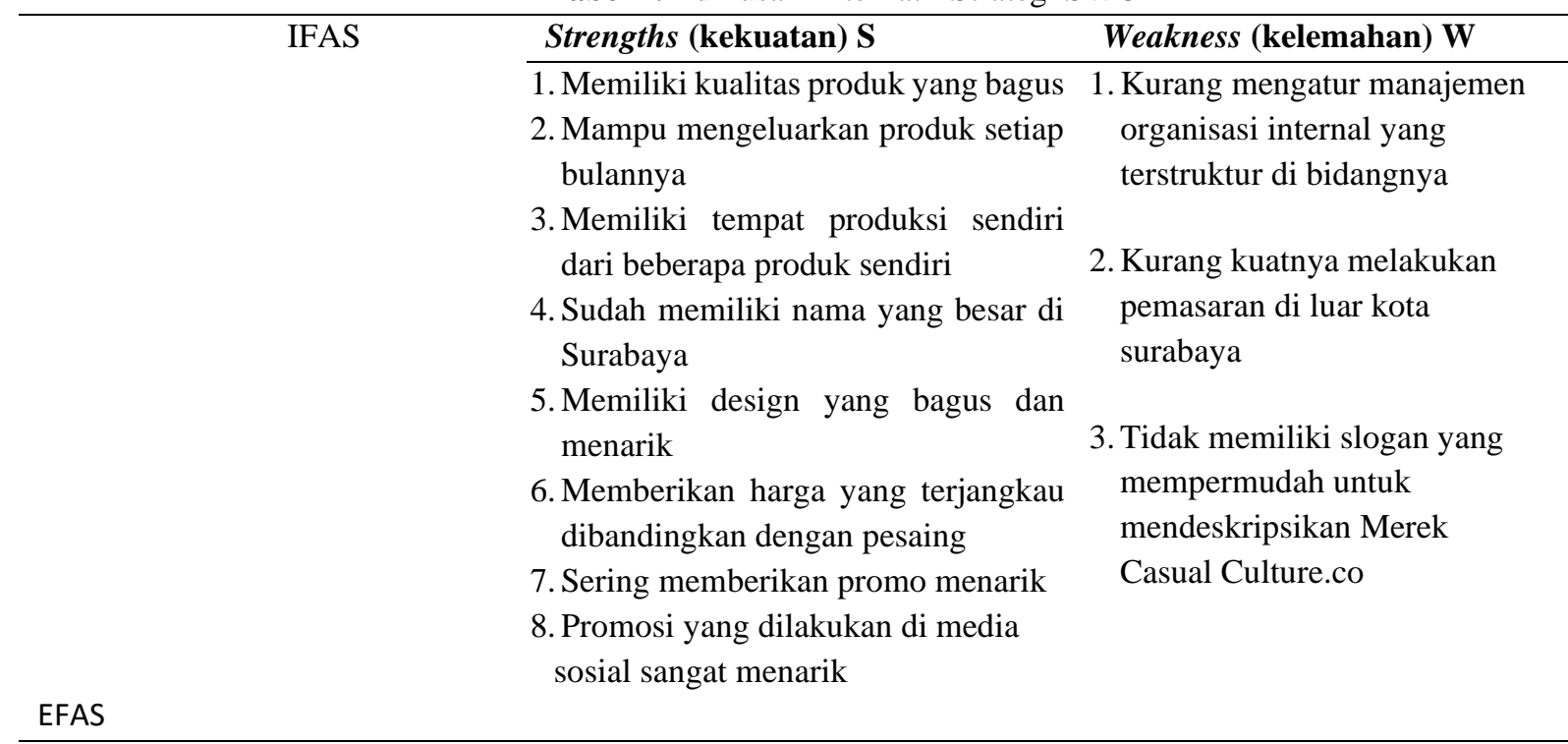




\section{Opportunity (peluang) $\mathrm{O}$ \\ 1. Mengadakan kolaborasi dengan brand lain agar peluang pasar Casual Culture semakin luas. \\ 2. Memaksimalkan perkembangan teknologi dengan adanya media sosial dan internet}

3. Mengikuti pameran clothing pada event tertentu guna untuk menaikkan produk yang ditawarkan Casual Culture agar lebih dikenal masyarakat luas

4. Mengedukasi konsumen mengenai support produk lokal, membuat image Casual Culture menjadi digemari kembali dan dapat bersaing dengan produk luar negeri yang serupa (Clothing)

5. Mengadakan kolaborasi dengan seniman lokal (Band, Graffiti) untuk deaign produknya.

6. Memiliki web resmi untuk memudahkan konsumen berbelanja online

7. Menambah design pakaian yang simple dan iconic agar diminati semua kalangan
Strategi SO

1. Lebih meningkatkan kegunaan perkembangan teknologi dengan adanya media sosial dan internet, agar juga dapat mempermudah konsumen berbelanja online 2. Meningkatkan kualitas produk yang lebih bagus dan menambah design yang menarik untuk dapat menambah minat beli konsumen

3. dengan cara mengadakan kolaborasi dengan brand lain semakin meningkatkan edukasi pada konsumen terkait brand lokal.

4. memberikan promo menarik dengan mengikuti pameran clothing pada event tertentu untuk menaikkan produk yang ditawarkan Casual Culture agar lebih dikenal masyarakat luas dan menarik minat beli ketika memberikan promo menarik seperti (dicount, buy 1 get 1 , dan bundling)

5. sudah memiliki nama yang cukup besar di surabaya memudahkan untuk menggandeng seniman lokal yang cukup terkenal untuk berkerjasama atau kolaborasi untuk membuat produk Casual Culture untuk menaikkan minat beli konsumen.

Strategi ST

1. Kurang tanggapnya dalam mencari informasi terkait trend yang sedang boming

2. Semakin banyaknya pesaing sejenis di bidang yang sama

3. Masih adanya masyarakat yang lebih memilih merek luar negeri yang lebih terkenal dibanding produk lokal sendiri.

4. Peraingan harga dengan brand baru yang harganya lebih rendah.
1. Memilih cakupan pasar yang lebih luas dengan meningatkan kualitas agar brand image Casual Culture semakin baik di pasar.

2. meningkatkan kualitas produk dan pelayanan seacara baik kepada konsumen, memperbanyak produk yang ditawarkan oleh Casual Culture, agar konsumen tertarik dengan produk lokal dibanding produk luar negeri

3. Mempertahankan harga yang terjangkau agar konsumen tetap memilih produk Casual Culture

4. Memberikan promo yang menarik, untuk meningkatkan jumlah penjualan dan agar konsumen lebih memilih produk Casual Culture dibandingkan brand lain.
Strategi WO

1. Merekrut pegawai yang dibutuhkan seperti manajer, untuk mengatur keseluruhan yang terjadi di lapangan, bendahara, untuk mengatur keuangan dalam perusahaan,

2. Mengadakan kolaborasi dengan merk ataupun seniman local untuk membuat produk dan di lounchingkan pada saat mengikuti pameran clothing pada event tertentu untuk menarik minat konsumen untuk datang pada acara tersebut.

3. Membuat kolaborasi dengan seniman maupun brand lokal di luar Surabaya untuk menambah cakupan peluang pasar.

4. Penambahan Slogan dengan pembuatan kata kata yang simple yang mudah di ingat konsumen.

Stratei WT
1. Perekrutan pegawai yang
dibutuhkan dibidangya agar
mengoptimalkan di segala
aspek kelemahan.
2. meningkatkan dan harus
tanggap dalam mencari
informasi yang sedang boming
agar dapat mencakup pasar
lebih luas dan dapat
memanfaatkan keadaan yang
sedang boming untuk
melakukan promosi produk
Casual Culture
3. Pembuatan slogan agar dapat
mudah di ingat oleh
masyarakat bahwa Casual
Culture merupakan brand yang
dapat memenuhi salah satu
kebutuhan primer

\section{SIMPULAN}

Berdasarkan hasil analisis yang dilakukan di Casual Culture.co Surabaya, peneliti dapat menarik kesimpulan sebagai berikut:

1. Hasil dari penelitian ini menunjukkan bahwa strategi branding produk dengan menggunakan atribut produk yang meliputi segi kualitas, fitur produk, desain, kemasan, label, pelayanan, jaminan, harga 
serta komponen identitas merek yaitu nama marek, logo dan simbol, tagline atau slogan, karakter atau maskot, jingle, URL atau domain web pada Casual Culture.co Surabaya yaitu sebagai berikut:

a. Memiliki tempat produksi sendiri dari beberapa produk sehingga dapat konsisten melakukan inovasi dan pengembangan produk baru, baik dari aspek desain maupun keragaman produk serta senantiasa membatasi jumlah produksi untuk menghindari menjadi produk "pasaran" sehingga setiap produk Casual Culture bersifat eksklusif.

b. Penggunaan kualitas produk, harga produk, desain, serta jaminan sebagai sarana untuk mengembangkan brand image di konsumen dengan menggunakan perangkat pendukung seperti sosial media, pelayanan, dan desain lingkungan toko

c. Konsep desain, gaya desain dan pengembangan produk, setia mengacu pada aspirasi pribadi Casual Culture;, sehingga menghasilkan produkproduk yang unik berkarakter dan memiliki originalitas yang tinggi.

2. Dengan melalui analisis IFAS (Internal Strategy Factor Analisis Sumarry) dan EFAS (Eksternal Strategy Factor Analisis Sumarry) dapat diketahui bahwa Casual Culture memiliki skor dari faktor internal yaitu, kekuatan sebesar 1,83 dan kelemahan memiliki skor 1,12, sedangkan dari faktor eksternal memiliki skor peluang 1,61 dan skor ancaman 1,22. 3. Hasil dari diagram analisis SWOT menunjukkan bahwa Casual Culture berada pada kuadran 1 (satu), dimana kuadran ini menunjukkan situasi yang sangat menguntungkan bagi perusahaan dengan itu Casual Culture memiliki peluang dan kekuatan lebih besar sehingga dapat memaksimalkan seluruh potensi internal untuk memanfaatkan peluang yang ada. Dalam hal ini, strategi yang dapat dilakukan Casual Culture mendukung kebijakan strategi pada tahap pertumbuhan yang agresif (Growth Oriented Strategy)

\section{Ucapan Terima Kasih}

Pada kesempatan ini peneliti menyampaikan terima kasih kepada seluruh pihak yang telah membantu peneliti dalam menyelesaikan penelitian ini diantaranya owner atau pemilik yaitu Fani Wahyu yang telah memperkenankan Casual Culture. Co sebagai objek penelitian ini, serta seluruh karyawan yang telah meluangkan waktunya untuk kegiatan wawancara dalam penelitian ini, peneliti ucapkan juga kepada teman - teman saya yang telah membantu, dan mensuport dalam menyelesaikan penelitian ini, semoga penelitian ini dapat berguna bagi orang yang membacanya dan bermanfaat untuk referensi penelitian selanjutnya.

\section{DAFTAR PUSTAKA}

Fandy Tjiptono, Gregorius Candra, dan Dedi Adriana, Pemasaran Strategic, 1 ed. (Yogyakarta: ANDI, 2008)

Hasan, A. (2013). Marketing dan Kasus-Kasus Pilihan. Yogyakarta: Caps Publishing

Keller, Kevin Lane, 2013. Strategic Brand Management 4th Global Ed. Boston: Pearson

Kotler, Philip dan Kevin L. Keller, 2008. Manajemen Pemasaran, Edisi Tiga Belas. Jakarta: Erlangga. Rivai, A., \& Prawironegoro, D. (2015). Manajemen Strategis. Jakarta: Mitra Wacana Media

Rungkuti, Freddy. 2016. Teknik Membedah Kasus Bisnis Analisis SWOT Cara Perhitungan Bobot, Rating, dan OCAI. Jakarta: PT Gramedia Pustaka Utama.

Sugiyono. 2015. Memahami Penelitian Kualitatif. Bandung: Alfabet

Sugiyono. 2017. Metode Penelitian Kuantitatif, Kualitatif, dan R\&D. Bandung: Alfabeta.

Tjiptono, F. (2012). Pemasaran Strategik. Yogyakarta: ANDI

Thamrin Abdullah dan Francis Tantri, Manajemen pemasaran, hal. 1

Tjiptono, F. (2008). Strategi Pemasaran. Yogyakarta: ANDI 